\title{
The secular problem of evil: an essay in analytic existentialism
}

\author{
PAUL PRESCOTT \\ Department of Philosophy, Syracuse University, Syracuse, New York, 13244, USA \\ e-mail: papresco@syr.edu
}

\begin{abstract}
The existence of evil is often held to pose philosophical problems only for theists. I argue that the existence of evil gives rise to a philosophical problem which confronts theist and atheist alike. The problem is constituted by the following claims: (1) Successful human beings (i.e., those meeting their basic prudential interests) are committed to a good-enough world; (2) the actual world is not a good-enough world (i.e., sufficient evil exists). It follows that human beings must either (3a) maintain a state of epistemic ignorance regarding the nature of the actual world or (3b) abandon their basic prudential interests. Theists resolve this problem by rejecting (2), only to confront the problem of evil as it is traditionally understood. Successful atheists also reject (2), but without adequate grounds for doing so.
\end{abstract}

Something might be true while being harmful and dangerous in the highest degree. Indeed, it might be a basic characteristic of existence that those who would know it completely would perish.

NIETZSCHE

In the Anglo-American philosophical tradition, the problem of evil is the problem of reconciling the existence of evil with the purported existence of God. On some versions of the problem, the existence of evil is held to be logically incompatible with the existence of God; on others, it is held to be evidence against the existence of God. On all versions, the philosophical problem posed by the existence of evil begins and ends with a commitment to theism. Reject theism and all that remains of the problem of evil is a practical task of reconciling oneself to a world in which evil exists. ${ }^{1}$

While this assessment is common, I believe it is mistaken. The classical (or theological) problem of evil is strictly a problem for theism. The philosophical problem posed by the existence of evil is not. Much as Schopenhauer once suggested, the existence of evil gives rise to a problem that is logically prior to the theological problem, and distinct from the practical one. ${ }^{2}$

I call this problem the secular problem of evil.

Here is a preliminary outline of the problem. It arises out of a basic empirical fact about human beings, which I will treat as given: human beings are vulnerable. We can be physically compromised. And we can be psychologically broken. Hence, we have basic prudential interestsincluding important psychological interests — which must be met if we are to be successful. 
Now, let us call a world 'good-enough' if and only if it is compatible with our unbenighted success. On the one hand, as I will argue:

(1) Successful human beings are committed to a good-enough world.

On the other hand, there is a claim which everyone should grant: evil exists. With the existence of evil comes a live possibility:

(2) The actual world is not a good-enough world.

By the 'actual world', I mean everything that is — both natural and supernatural - including that which is socially constructed. ${ }^{3}$ By a 'successful human being', I mean a human being that is meeting their basic prudential interests and, in so doing, succeeding psychologically as a person. By 'committed', I refer to a dependence relation that is inextricably and irreducibly affective (Stocker (1983)). As I will understand them, human beings are affect-laden creatures - with affectladen minds - that are born, live out their lives, and die embedded in a world to which they are existentially vulnerable. As a consequence, they need that world to be good-enough if they are to be successful. And by and large, they trust that it is. I will say more about the specific nature of this dependence relation in subsequent sections. The point for the moment is as follows: Should (1) and (2) be true, the true story of the actual world is affectively unbearable-i.e., psychologically traumatic from a human perspective. As such, it is incompatible with unbenighted human success. Under such conditions, every successful human being - theist and atheist alikenecessarily lives under a blanket of self-protective illusion.

Let us call the view that (1) and (2) are true 'tragic realism'. According to the tragic realist, the human condition is defined by a fundamental conflict between our epistemic and prudential interests. Confronted with the existence of evil, we can either

(3a) abandon epistemic integrity

or

(3b) abandon our basic prudential interests.

Neither option is attractive. The first entails maintaining a self-preserving state of epistemic ignorance regarding the nature of the actual world. The second requires abandoning one's psychological success and well-being as a person.

Now, one might be tempted by the first option. Practically speaking, not thinking too closely about evil is among the more effective means of reconciling oneself to a world in which evil exists. Such reconciliations, however, come at a considerable cost. In the actual world, human affairs are routinely conditioned by the existence of evil. Thus, in not attending too closely to evil (and thereby, not understanding it sufficiently well) one can easily render oneself ill-equipped relative to important human concerns. There are central areas of philosophy, for example- 
including ethics, moral psychology, and social/political philosophy-where a clear-eyed appreciation of the existence of evil is essential to responsible engagement. The possibility that tragic realism is true is thus a matter of no small concern.

I approach the problem in five stages. In the first four, I present the secular problem of evil simpliciter — which confronts theist and atheist alike — and make the case for tragic realism as a philosophically viable option. First, I explicate the central notion of a good-enough world. Second, I make the case that successful human beings are committed to the actual world being a goodenough world. Third, I consider and reject the current philosophical response to the secular problem of evil: an assumption that successful human beings are possible in what I define as a 'not good-enough' world. Fourth, I consider and reject an argument that the actual world can be known to be good-enough a priori. With that foundation laid, I turn to the secular problem of evil for atheism, and to the challenge the existence of evil poses for those who reject a religious worldview. I contend that the successful atheist is committed to the actual world being good-enough, despite substantial evidence that it is not.

My aim throughout is not to defend theism. On my view, theism is indefensible. Nor is it my aim to convince the atheist that we do not live in a good-enough world. If I am right, no one is in a position to know whether the world in which we live is good-enough or not. Rather, my aim is to show that the existence of evil poses a problem for philosophy which cannot be escaped by rejecting a religious worldview.

Let us now turn to the concept of a good-enough world.

\section{The Concept of a Good-Enough World}

The concept of a good-enough world stands on two assumptions. ${ }^{4}$

The first assumption is that the human personality is fragile. By the 'personality', I mean the integrated features of a person - including traits of character - that are typical of that person as an individual. The personality, as I will understand it, is an essential aspect of the self, one constitutive of human beings qua human. Hence, one can have a damaged personality; but one cannot lack a personality altogether. By 'fragile', I mean that our personalities are dependent upon, and existentially vulnerable to, a world which they inhabit, and in which they reside. ${ }^{5}$ Much as the human organism depends upon a world to provide the physical conditions necessary for its ongoing integration and survival - for example, food, shelter, oxygen, and atmospheric pressure — so the human personality depends upon a world to provide necessary conditions also. Foremost are those required to maintain a capacity for thought and action, as I will argue in subsequent sections. These necessary conditions comprise our basic prudential interests, which must be met if we are to be successful. $^{6}$

The second assumption on which the concept of a good-enough world stands is what Hume once called the 'great and melancholy truth': evil exists ((2007 [1779]), 68). Some in the twentieth century have suggested that 'evil' has no meaning outside of a theological context (cf. 
Garrard (2002), 322-326). I will hold that it does. Evil, as I will understand it, is that which undermines the personality. Evil is not merely bad for us. Rather, it threatens to undo us entirely.

Let us say that a world is good-enough if and only if our basic prudential interests can be met, and our personalities sustained, in a full, uncompromised awareness of the existence of evil. A good-enough world is a world that human beings can bear to confront, at least in principle. It does not exceed the limits of what the human psyche can bear at a fundamental level.

What makes for a good-enough world, thus understood? As means of approach, several basic distinctions will give the concept a thicker and more tractable definition. Here, I will exposit three possibilities, which are intended to be exhaustive. A world can be (1) karmic, and therefore enabling of the human personality; it can be (2) nonkarmic, yet nonetheless enabling of the human personality; or it can be (3) disabling of the human personality. ${ }^{7}$ Worlds that are enabling are goodenough. Worlds that are disabling are not.

\section{Karmic-Enabling Worlds}

Let us call a world that is necessarily enabling of the human personality a 'karmic-enabling world'. Here, we find the world as it is understood by most theists. Karmic-enabling worlds are necessarily enabling because they are morally-ordered at a fundamental level. In virtue of their moral order, karmic-enabling worlds render our basic prudential interests secure.

Consider the following: moral order provides a world with two important features, which radically mitigate the existential threat posed by the existence of evil. First, moral order allows for the possibility of adaptation. For any personality confronted with the existence of evil, there is at least one constructive response available. In a morally-ordered world, one can protect oneself by being a good person. In light of our inherent fragility, not every form of life is sustainable by us in the face of the existence of evil. For example, as Schopenhauer was quick to remind us, many forms of life prove to be mere vanity and illusion. ${ }^{8}$ Nevertheless, adaptation is always possible in a morally-ordered world, for there is always at least one form of life-namely, a moral form of life - that is neither vanity nor illusion, and which can be successfully adopted by creatures like us. By adapting oneself to the moral order, one can ensure that one's basic prudential interests will (ultimately) be met thereby rendering oneself existentially secure.

Second and closely related to the first, moral order provides for a degree of control. Not every course of action is possible for us in the face of the existence of evil. Indeed, there is a very great deal which is beyond our limited capacities as human agents. Nevertheless, in a morallyordered world, we are never wholly impotent. At least one course of action capable sustaining the personality - namely an embrace of the moral order - is always within our scope.

In providing these twin features, karmic-enabling worlds provide the conditions necessary to maintain a clear-eyed, uncompromised trust in the world despite the existence of evil. While evil may exist in a karmic-enabling world, its existence is subsumed under a larger order in which we and our basic prudential interests are secure. Immanent justice follows: personalities which (ultimately) fail in a karmic-enabling world do so because they have chosen to fail-and hence deserve to fail-as persons. 
Now, most atheists maintain that the idea that we live in a karmic-enabling world is deluded. Human beings have a powerful tendency to posit such a world, as Lerner (1980), among others, has shown. And karmic-enabling conditions are often presupposed. For example, Abrahamic monotheism, Buddhist nontheism, Hindu henotheism, Plato in the Republic, and (arguably) Kant all presuppose a karmic-enabling world. Nevertheless, many trust the world to be sufficiently hospitable to us in the absence of a fundamental moral order.

For these others, the world is a nonkarmic yet enabling world.

\section{Nonkarmic-Enabling Worlds}

Let us call a world that remains sufficiently enabling of the personality in the absence of karmic ordering a 'nonkarmic-enabling world'. Here, we find the world as it is understood by most atheists. Nonkarmic-enabling worlds remain enabling because they are sufficiently well-orderedin some significant nonmoral sense - to allow for the possibility of human adaptation and control.

For the purposes of this paper, I will leave the precise conditions necessary for the possibility of human adaptation and control underdetermined. Some such conditions are readily identifiable: a world cannot be too capricious, for example. Nor can it be too unintelligible. Nor can conditions within it be too abusive from a human perspective. Nevertheless, while the precise conditions required for the possibility of human adaptation and control are an important topic in their own right, for the purposes of this paper they are irrelevant. It suffices to say that there are some. Provided such conditions, a nonkarmic-enabling world is good-enough. It is sufficiently viable from a human perspective that creatures like us can - at least, in principle — satisfy our basic prudential interests without recourse to illusion. Here, for example, we find the world defended at length by Nietzsche, and presupposed by Karl Marx and John Stuart Mill. A nonkarmic-enabling world is not always conducive to us. And there are no guarantees (as there are in a karmic world). But confronted with the reality of evil, it remains possible for us to provide for ourselves unbenighted. ${ }^{9}$

There is, however, a third option.

\section{Disabling Worlds}

Let us call a world that is not sufficiently conducive to us a 'disabling world'. Disabling worlds are fundamentally incompatible with the conditions upon which we depend. Should the world be disabling, human aspirations are without rational basis. Control is an illusion. Adaptation requires illusion also. In reality, our requirements will not be met.

It is at this point - much as Nietzsche once noted - that philosophers typically part ways with tragic poets. ${ }^{10}$ For philosophers, the actual world may or may not be karmic. But it is enabling. For the tragic poets, the actual world is not. Not only is the world portrayed by the tragic poets nonkarmic, but it utterly outstrips the finite capacities of human beings to meaningfully compensate or respond. Here, for example, we find the world portrayed by Sophocles in Oedipus Tyrannus and by Shakespeare in King Lear. 
Now, it is not my intention to argue that the world is disabling. I merely seek to give the notion a hearing. Toward that end, two points are in order.

First, the possibility of a disabling world can be difficult to entertain for reasons that have nothing to do with the truth or falsity of the thesis. Entertaining the possibility of a disabling world requires acknowledging that one is psychologically, existentially, and intellectually vulnerable in ways that can be deeply unsettling. This experience-the experience of our own fragility - is something we typically defend ourselves against. Our affect-laden minds routinely employ a wide range of techniques - both cognitive and noncognitive - with the aim of preserving our success and our psychological well-being. ${ }^{11}$

Second, a disabling world need not be bad in every particular. Indeed, it can contain a great deal of good fortune. There can be seemingly good-enough environments within it - islands of comparative enablement - capable of underwriting some personalities in relative privilege and comfort. Of course, if the world is disabling such personalities will be deluded regarding the nature

of the actual world. But that is precisely the point. It is entirely possible to live in a disabling world without ever recognizing — much less acknowledging — its disabling order, a point to which I will return.

But first, let us turn to tragic realism, and the claim that successful human beings are committed to an enabling world.

\section{Tragic Realism}

Tragic realism is the view that the actual world fundamentally exceeds the parameters set by the affect-laden human mind. As noted in the introduction, the view is comprised of two claims:

(1) Successful human beings are committed to a good-enough world.

(2) The actual world is not a good-enough world.

In the previous section, I unpacked the second claim. Here, I focus on the first. For convenience, I will refer to (1) as the 'key assumption' of tragic realism.

At this point one might ask: why accept the key assumption? In addressing this question, I will draw upon two arguments. The first I call the argument from human development; the second, the argument from posttraumatic aetiology.

\section{The Argument from Human Development}

The argument from human development begins with an observation: children trust in a good-enough world. They do so necessarily, as a requirement of the developmental process. Trust in a good-enough world - and hence an acceptance of the key assumption - is a foundational condition of childhood. Children cannot be children without it. 
Consider the following: children are oblivious to many—perhaps most—of the existential dangers that surround them. That the world is a safe place to grow and explore, for example, is a given (whether or not the world is). That their parents are good people who love them is a given also (whether or not their parents are, or do). These and similar confidences are the bedrock of childhood. The possible contraries are simply too terrifying for a child to endure. As a consequence, the key assumption of tragic realism is satisfied in the case of children. Children need the world to meet certain requirements, and they trust that the world meets those requirements whether or not the actual world does.

Now, many of us tacitly assume that this state of affairs comes to an end with the advent of adulthood. But does it?

Contemporary psychologists maintain that it does not.

According to the basic tenets of contemporary psychology, trust in a good-enough world is foundational not only for childhood development but also in the resulting architecture of the adult personality. This claim is well-established - and widely accepted - throughout the psychological sciences. Support for its truth can be found in nearly all texts concerned with the development and architecture of the adult personality. On Erikson's pioneering view, for example, 'basic trust' serves as the necessary foundation of all subsequent development across the life-span ((1959), 57-63). Comparably, Bowlby's canonical attachment theory posits successful attachments (that is, relations of trust) as 'central features of personality functioning throughout life' ((1988), 123). The terminology employed varies, but the basic claim expressed does not. Psychologists, psychiatrists, and psychoanalysts all maintain that trust in a good-enough world is a necessary condition of the personality, which can never be outgrown.

Here, two points of emphasis are called for.

First, it is important to remain cognizant that the use of the term 'trust' is not intended to indicate that one must believe that the world is good-enough (on an intellectualist understanding of 'belief'). The kind of trust under discussion is affective, not cognitive. ${ }^{12}$ Hence, our trust in a good-enough world is not necessarily seen in our cognitive attitudes, much less in the propositions we endorse. One can trust the world while asserting, and believing, that one does not. Indeed, this is all too common. Many people believe that they do not trust the world. And many people are mistaken. We inhabit a 'climate of trust' that, as Annette Baier once observed, typically goes unnoticed unless compromised or absent ((1986), 234).

Second, as noted at the outset, the secular problem of evil is not a practical problem. It is not the problem of reconciling oneself to the existence of evil, either with or without God. Considered strictly on a practical level, human beings need not concern themselves overly much with the nature of the actual world. All that is required is a good-enough world for us - that is, a good-enough local environment. And there are such good-enough local environments. As previously noted, some people have the privilege, and the good fortune, of living in one. ${ }^{13}$ Regardless of one's personal fortunes, however, the possibility of tragic realism does arise once one begins asking about the nature of the actual world - that is, about the fundamental human 
condition. Here, there are reasons to conclude that 'human kind | [c]annot bear very much reality', much as T. S. Eliot once noted ((1943), 14).

Let us now turn to the second argument in support of the key assumption of tragic realism, one less reliant on the explanatory commitments of the psychological sciences.

\section{The Argument from Posttraumatic Aetiology}

The second argument for the key assumption of tragic realism is empirical, and premised on cases where trust in a good-enough world has been forcibly broken. Here we encounter the material reality which underwrites the secular problem.

As the foregoing might suggest, our foundational trust in the world is not easily disrupted. Basic trust, once forged, is remarkably resilient. It cannot be readily shaken. But it can be broken, whether accidentally or by intent. Accidentally, it can be undermined by catastrophic misfortune (traditionally known as 'natural evil'). Intentionally, it can be undermined by severe abuse or psychophysical torture (traditionally known as 'moral evil'). In both cases, when trust is sufficiently compromised, the personality is compromised as well.

The current clinical term for what transpires once trust has been sufficiently compromised is 'posttraumatic stress disorder.' First identified by Pierre Janet in the $19^{\text {th }}$ century (1889), and officially recognized by the American Psychiatric Association in the $20^{\text {th }}$ (1980), posttraumatic stress is now a well-established clinical phenomenon. ${ }^{14}$ Central to our understanding of posttraumatic stress is the recognition that the personality is fragile. Deprived of a sustaining environment - that is, placed under sufficient duress - the personality breaks down.

When the personality breaks down, one encounters a catastrophic disorganization of otherwise stable features and capacities, both affective and cognitive. A sense of self which was previously coherent is fractured. Character traits which were previously reliable become disordered. Basic affective and cognitive capacities - including capacities for thought, memory, and action-fail (Shay (1994), 165-181). In short, the human capacity for practical reason is undermined, in tandem with the subjectivity of the individual in question. When our necessary conditions fail to be met, we come up against what Auschwitz survivor Jean Améry once aptly called 'the mind's limits' (1966).

Here, two further clarificatory points are in order.

First, in speaking of the 'human capacity' for practical reason, it is not my intent to suggest that practical reason per se requires a good-enough world. It is conceivable, for example, that beings not subject to our fragility would be able to reason practically in what is, for us, a disabling world. The point is merely that whatever may be true of such beings, it is not true of us.

Second, in addressing 'posttraumatic stress disorder' it is not my intent to suggest that people suffering from posttraumatic stress are unable to practically reason. Obviously, they are. Rather, the point is that unlike every other phenomenon in the psychiatric cannon, the condition we currently call 'PTSD' has a well-established aetiology - that is, an identified cause. That cause is the experience of evil (as evil is defined here), which compromises the personality and its capacity for thought and action. Naturally, a capacity for practical reason returns once safety has 
been reestablished. Nevertheless, at least for a brief period, the subject experiences a disabling world.

Now, what exactly is compromised along with the personality in such cases? As suggested by the taxonomy of worlds previously presented, the precise content of our sustaining commitments appears to vary. For some, maintaining the requisite capacity to think and act appears to require trust in a world that is karmic. Such individuals are committed to a world that is morallyordered at a fundamental level and are unable to organize themselves without it. For others, comparable self-maintenance requires commitment to a world that, while nonkarmic, is nonetheless enabling. Such individuals trust in a world that is sufficiently well-ordered to allow for at least the possibility of meaningful thought and action. For no successful personality, however, can the world be disabling. One can be committed to a karmic world, or merely to one that is enabling. But regardless of which commitment one embraces, traumatic experience will violate that commitment with consequences that are clinically predicted. In the aftermath of traumatic experience, both self and world cease to make sense to the survivor (Janoff-Bulman (1992), 4969).

Thus, we arrive at the material reality which underwrites the key assumption. Human beings are committed to a world that is sufficiently well-ordered from a human perspective to allow for meaningful thought and action. And successful human beings trust that they live in such a world. That the actual world is not a good-enough world is a logical possibility. But it is not an existential one. It is not a possibility for us. Insofar as we wish to maintain our personalities and our psychological well-being, we are demonstrably committed to the conditions upon which we depend.

Having made the case for the key assumption of tragic realism, I now turn to two important and informative objections. The first is drawn from the work of Albert Camus; the second from that of Jonathan Lear.

\section{The World is Beautiful, and Outside There is No Salvation}

Let us begin with the contemporary philosophical response to the secular problem of evil. The move is to change the subject to aesthetics, and away from metaphysics and morals. On the resulting view, the actual world may not be good-enough - at least, not in the sense under discussion. But it is beautiful. And because it is beautiful, successful human beings are possible.

Here, for example, we find the work of Albert Camus. ${ }^{15}$

\section{Camus' Views regarding the Human Condition and the Nature of the Actual World}

Camus shares the tragic realist's view that the actual world is neither karmic nor enabling. However, it does not follow for Camus that the actual world is disabling. For the sake of clarity, therefore, I will refer to Camus' view as the view that the actual world is 'nonenabling.' A nonenabling world is one in which successful human beings are possible, but in which our hopes 
and aspirations are necessarily frustrated. Such a world is not amenable to human intervention and ordering. In Camus' terms, it is 'absurd.'

Now, Camus maintains that an absurd world is not necessarily a disabling one. On Camus' view, a successful human life remains possible in an absurd world provided one surrenders to a life lived in the present without hope of consolation. Camus' position on this point, however, flirts with contradiction. Couched in the terms employed here, the world Camus describes can appear both good-enough and not good-enough at the same time. That being the case, it will be important to identify precisely what he is, and is not, saying.

On the one hand, Camus is clearly committed to the claim that the actual world is not enabling. He rejects the notion that the actual world is karmic: 'there is no salvation' ((1956b), 103). Likewise, he rejects the notion that the actual world could ever be rendered intelligible from a human perspective: '[t]he world in itself is not reasonable, that is all that can be said' ((1955), 21). On the other hand, Camus also holds that human beings are able to remain 'intact.' He makes this claim in his earliest essays ((1956b), 69), and maintains it throughout his life. Human being are able to remain intact because, despite the irrationality of the human condition, the world is beautiful. And so, 'there is always a place where the heart can find rest' (90).

Camus' point, as I understand it, is that the resources required to sustain our personalities are available to us even in a nonenabling world. In a famous passage, for example, Camus writes:

I discovered one must keep a freshness and a source of joy intact within, loving the daylight that injustice leaves unscathed, and returning to the fray with this light as a trophy. ... It was this that in the end had saved me from despair. ... In the depths of winter, I finally learned that within me there lay an invincible summer ((1956b), 168).

On the resulting view, the human condition is insurmountable. But it is not fundamentally undermining. Human beings remain able to secure their basic prudential interests even under conditions of absurdity. And so, it is possible for us 'to live without appeal' ((1955), 53).

\section{A Response to Camus on Behalf of Tragic Realism}

From the vantage point of tragic realism, Camus underestimates the depth of the problem posed by the existence of evil.

Let us stipulate that Camus is correct: the world is beautiful. Let us further stipulate that aesthetic appreciation and aesthetic activity remain possible in a nonenabling world. There is nothing entailed by this claim that rules out the possibility that the actual world is disabling. A world can contain beauty — or even be itself beautiful — and yet be no less disabling for creatures like us.

The problem confronting Camus is that he never argues for his central thesis. Camus holds that successful human beings are possible in a nonenabling world. But rather than provide reasons or evidence in support of his view, he provides literary illustrations. In his plays, essays, and novels, Camus portrays lives lived successfully under the conditions he describes. It is never asked 
whether the fact that we can imagine human beings living successfully under such conditions demonstrates that human beings actually can. It is simply assumed that it does. From the imaginable, the possible is taken to follow.

The tragic realist maintains that it does not follow.

According to the tragic realist, human beings can imagine being able to succeed in a nonenabling world much as they can imagine being able to breathe in outer space. In the actual world, they can do neither. Camus' Sisyphean heroes, in short, are phantasies-fictions that are appealing, in part, because they are able to do what we cannot. Like many of the protagonists favored by his existentialist contemporaries, Camus' individuals can succeed in a nonenabling world. Unlike actual human beings, they are not fundamentally vulnerable to psychological trauma.

Of course, Camus may be right that our trust in a good-enough world is unwarranted. And he also may be right that we are 'frustrated by the universe' as a consequence ((1956a), 23). But should the actual world not be good-enough, the problem is not merely that our hopes and aspirations are frustrated. The problem is that we are either hopelessly benighted or psychologically undone.

Having addressed the contemporary philosophical response to the secular problem of evil, I now turn to a recent alternative.

\section{Love and Its Place in Nature}

In his early work on the philosophical implications of Freudian psychoanalysis, Jonathan Lear affirms the key assumption of tragic realism. Like the tragic realist, Lear holds that there is a critical range of fit between the personality and the world in which it resides. And like the tragic realist, Lear holds that outside this range of fit the personality is unsustainable without recourse to illusion. This is not a problem for Lear, however, because on Lear's account the actual world is good-enough. Indeed, on Lear's account one can know that the actual world is good-enough a priori, for a world that is not good-enough 'is not a possible world' ((1990), 140). ${ }^{16}$

The argument is as follows.

\section{Lear's Argument on Behalf of a Good-Enough World}

Lear begins with the claim that the personality (or ego) is a psychological achievement, a condition of the possibility of which is a good-enough world. Lear also affirms that this can be seen in the fact that when the world is not good-enough the personality breaks down and one 'encounters psychosis' ((1990), 139). ${ }^{17}$

On Lear's account, however, this gives rise to a simple transcendental deduction:

1. A condition of the possibility of a successful personality is a good-enough world.

2. There are successful personalities.

3. Therefore, there is a good-enough world. 
In short, Lear maintains that the fact that there are successful personalities demonstrates the existence of a good-enough world.

Now, one might counter that Lear's argument only secures the existence of a good-enough local environment as a developmental condition of any given personality. And one would be correct. As it stands, the argument says nothing about the conditions that obtain in the actual world. Rather, it speaks only to the conditions that obtained in the limited environment in which an individual developed. Clearly, for example, insofar as I am a successful personality, there was a good-enough world for me. But, as we have seen, there is nothing in the existence of a goodenough world for me - an island of comparative enablement, in which defenses can be successfully mounted - that rules out the possibility that we live in a disabling world.

In anticipation of this objection, Lear's argument takes on an additional level. Human beings, he points out, are not possible in social isolation. Hence, a condition of the possibility of a good-enough world for me is a good-enough world for us. We-the community of successful human personalities - are here. Hence, not only is the world for me good-enough, but the world for us is good-enough also.

At this point, however, Lear makes an interesting move. Lear maintains that the world as it is experienced 'by us' successful personalities simply is the actual world:

It is a condition of there being a world that it be lovable by beings like us. ... This is more than a psychological condition of there being a world for us. There is no content to the idea of a world that is not a possible world for us. And a world that is not lovable (by beings like us) is not a possible world ((1990), 141-42).

On Lear's account, there is no conceptual space for a world above and beyond the world as successful human beings collectively encounter it. ${ }^{18}$

\section{A Response to Lear on Behalf of Tragic Realism}

Lear's account is correct up to (but not including) the point where the world as it is for us is equated with the actual world. Human beings need the world to be good-enough, and the world is experienced as good-enough by many human beings. The larger argument to the adequacy of the actual world, however, confronts a serious challenge.

The challenge is simple. It is not a necessary condition for the successful personality that the actual world be good-enough. There is another option: namely, that regardless of the conditions under which human beings exist, any successful human being will necessarily trust that the actual world meets their necessary conditions. In short, they will experience the world as good-enough, regardless of whether or not the actual world is. What has not been ruled out is the possibility that the actual world is the world experienced by the compromised personality - in Lear's terms, the psychotic. Nothing Lear says rules out the possibility that psychosis is warranted, in the sense of being an appropriate response to the world. He simply assumes that it is not. 
At issue here is the privileging of experience. Who counts as 'us' in Lear's 'for us'? If one wants to establish that this is, in fact, a good-enough world, one cannot rule out evidence and testimony to contrary from the start. And yet this is what Lear's transcendental argument effectively does. Having identified the psychotic as the bearer of contrary experience, the evidential weight of that experience is pre-emptively excluded. Here - as is so often the case in human communities, and among human beings - voices which disturb the prevailing consensus are simply not being given a hearing.

Lear is surely correct that we are here, alive, in the actual world. And he is also correct that some of us are successful. But why? Because the actual world is good-enough? Or because many of us possess robust (and highly advantageous) defenses that limit our ability to track the tragic reality?

Having laid the foundations in the preceding sections, I now turn — at long last — to the challenge the secular problem of evil poses for atheism.

\section{The Problem of Evil Cannot Be Escaped}

Let us return to the existence of evil and our tripartite taxonomy of worlds. It is one thing to maintain that evil exists. It is quite another to maintain that this is not a good-enough world. All three possibilities in our taxonomy of worlds - karmic-enabling, nonkarmic-enabling, and disabling - are compatible with the existence of evil. The question, therefore, is not whether evil exists. It does. Rather, the question is whether we live in a world that provides the resources necessary for us to cope with that fact unbenighted. The tragic realist maintains we do not.

It is at this point that the successful atheist confronts a serious challenge.

Successful atheists - that is, atheists who are meeting their basic prudential interests - take the alternative to a karmic-enabling world to be a nonkarmic-enabling, rather than a disabling, world. It is commonly assumed that removing the anthropocentric constraints on our metaphysics issues in a world that is indifferent, but not overtly hostile, to us. Much the same is assumed of the social world in the absence of a transcendent order. It is commonly assumed that we can meet our basic prudential interests without the benefit of a karmic environment. In short, it is assumed that the actual world provides the resources required.

The tragic realist posits a world that is disabling, and so incompatible with all such aspirations. And it is here that the atheist and the tragic realist typically part company. The successful atheist - like every successful human being - maintains modes of thought and action which presuppose that the world can be trusted.

The problem the successful atheist confronts is grounding that trust.

Consider the following: All three candidates in our taxonomy of worlds are compatible with the existence of evil. But not all three are comparable in this regard. Karmic worlds are distinct from nonkarmic worlds in one important respect. A karmic world, in virtue of being karmic, guarantees that the existence of evil will be met with a response. In a karmic world, the existence of evil is subsumed within a moral order which guarantees that our basic prudential interests can 
be secured. There is no comparable guarantee in a nonkarmic world. In a nonkarmic-enabling world, evil may not be met with a response. In a disabling world, it will not be met with a response. Evil is thus compounded in nonkarmic worlds in ways in which, in karmic worlds, it is not.

This compounding of evil — this failure to be met with a response - is itself an evil, and a significant one. If experiencing evil is bad, being abandoned to evil is worse. Evils that are thus compounded are significantly greater threats to success of the personality than evils that are not. As research on posttraumatic stress has consistently shown, our personalities can survive a great deal provided sufficient social support, and thereby at least the possibility of successful adaptation and control (Herman (1992), 214-236). On the other hand, our existential condition is dramatically more precarious when the requisite support is absent or withdrawn. This phenomenon-first dubbed the 'second injury' by Martin Symonds - is now well documented. ${ }^{19}$

Let us call evil that fails to be met with a response 'significant evil'. Significant evil is evidence — albeit, not conclusive evidence — of a not good-enough world.

Now, most atheists are deeply committed to existence of significant evil. Indeed, the typical atheist does not merely hold that significant evil exists. Rather, the typical atheist holds that significant evil is pervasive. It is the pervasive existence of significant evil, for example, that many find so persuasive - and hence, which serves the atheist so well — in arguments from evil against the existence of God. Evils that can be folded into a greater good are not a problem for theism. Evils that cannot be reconciled or redeemed are. ${ }^{20}$ Here, Dostoevsky's famous discussion in Book V, Chapter 4 of The Brothers Karamazov is both eloquent and instructive. ${ }^{21}$

That being the case, the problem the successful atheist confronts is straightforward. Once one has admitted the pervasive existence of significant evil, there is no principled way to stop. One cannot consistently commit to the pervasive existence of significant evil in arguments from evil against the existence of God only to bracket, minimize, or dismiss its relevance elsewhere. And yet, this is what the successful atheist typically does. ${ }^{22}$ When it comes to the claims at issue, there is nothing to which the tragic realist points that the typical atheist does not readily admit. Significant evil exists. It is pervasive. Our necessary conditions routinely fail to be met. On many occasions, in many people's lives, the world simply cannot be trusted. These same premises that serve the atheist so well in arguments about the existence of God will serve the tragic realist equally well in arguments about the nature of the actual world.

Now, at this juncture one might note that the atheist's commitment to the pervasive existence of significant evil is cognitive. As such, it would seem to be importantly distinct from the affective commitments that give rise to the secular problem. Hence, one might reasonably ask: cannot the atheist be cognitively committed to the pervasive existence of significant evil without thereby encountering the secular problem?

The short answer, unfortunately, is 'no.' As the tragic realist will be quick to point out, once one has endorsed the claim that pervasive significant evil exists, the existential implications of one's conviction inexorably follow.

Of course, it remains possible that we live in a good-enough world. Nothing in the foregoing demonstrates that we do not. The problem is that confidence in these matters is now 
suspect, on a par with atheism's prevailing suspicions regarding religious conviction in general. We trust in a good-enough world, just as we once trusted in providence, moral order, and God. But much as Freud once suggested regarding those latter three: 'it is a very striking fact that all this is exactly as we are bound to wish it would be' ((1961 [1928]), 42).

Thus, we arrive at an uncomfortable conclusion. The successful atheist does not know the actual world is good-enough. But the successful atheist maintains a commitment that it is. And so, the successful atheist is committed to a kind of faith: no less than the faith of the theist, albeit not a faith in God. Where the successful theist takes it on faith that significant evil does not exist (God ultimately meeting every evil with a response), the successful atheist takes it on faith that the existence of significant evil, while pervasive, is not decisive.

The faith of atheism, in short, is faith in a good-enough world.

\section{Concluding Remarks}

The pursuit of truth defines philosophy. But it has always come with a shadow: the possibility that the truth, should it be known, would be unbearable. This problem is not merely a skeptical problem. It is not merely a problem about the possibility of knowledge (although it is that also). Nor is the problem one of nihilism. At issue is not the absence of truth, or value, or meaning. Rather, the problem is one of a qualitatively different kind. The problem is that the true story of the world could be beyond the endurance of the affect-laden human mind.

In his Meditations, Descartes briefly entertains worries of this general kind. For a brief moment, it is supposed that the actual world is not good-enough - God being a malicious deceiver-and hence that the mystifications of childhood are insurmountable. ${ }^{23}$ This problem, once raised, is quickly bypassed in favor of the projects of the prevailing age. In the Meditations, the challenges posed by the secular problem of evil are set aside in favor of the challenges posed by radical skepticism and the epistemic foundations of the modern sciences.

There is, however, such a thing as the secular problem of evil. If the foregoing consideration are correct, it not only underwrites the world's religious traditions but remains once religious convictions are gone. ${ }^{24}$ Childhood aspirations that can be outgrown are one thing. Fundamental requirements that can never be relinquished, or overcome, are another. That the world is not morally ordered for our benefit is something which, presumably, human beings can learn to accept (though here it can hardly be overstated how loathe some are to accept this). That the world is fundamentally incompatible with a human life lived in full appreciation of its existential condition, on the other hand, may well be 'unacceptable' in the sense of being something that simply cannot be accepted - at least, not by a mentally and emotionally healthy human being.

At present, the secular problem of evil appears irresolvable. We may not live in a goodenough world. Should that be the human condition, there are only two unpalatable options. One can abandon one's basic prudential interests in order to retain contact with the tragic reality. Or 
one can abandon epistemic integrity and live in a self-preserving state of ignorance regarding the evil nature of the actual world. ${ }^{25}$

\section{References}

ADAMS, M. M. (1989) 'Horrendous Evils and the Goodness of God', Proceedings of the Aristotelian Society, 63, 297-310.

AMERICAN PSYCHIATRIC ASSOCIATION (1980) Diagnostic and Statistical Manual of Mental Disorders. Third ed. (Washington, DC: American Psychiatric Publishing).

AMÉRY, J. (1966) At the Mind's Limits: Contemplations by a Survivor on Auschwitz and Its Realities. Trans. S. Rosenfeld, S. P. Rosenfeld (Bloomington: Indiana University Press).

BAIER, A. (1986) 'Trust and Antitrust', Ethics, 96, 231-60. - (1980) 'Secular Faith', The Canadian Journal of Philosophy, 10, 131-48.

BOWLBY, J. (1988) A Secure Base: Parent-Child Attachment and Healthy Human Development (New York: Basic).

BRISON, S. J. (2002) Aftermath: Violence and the Remaking of a Self(Princeton: Princeton University Press).

BURCHARD, M. (2019) Philosophical Reflections on Mothering in Trauma (London and New York: Routledge).

CAMUS, A. (1956a) The Rebel: An Essay on Man in Revolt. Trans. A. Bower (New York: Vintage). - (1956b) Lyrical and Critical Essays. Ed. P. Thody. Trans. E. C. Kennedy (New York: Vintage). - (1955) The Myth of Sisyphus and Other Essays. Trans. J. O’Brien (New York: Vintage).

DERRIDA, J. (1996) 'Faith and Knowledge: Two Sources of 'Religion' at the Limits of Reason Alone' in G. Anidjar (ed.) Acts of Religion (London and New York: Routledge), 42-100.

DESCARTES, R. (1988 [1641]) 'Mediations on First Philosophy' in J. Cottingham, R. Stoothoff, D. Murdoch (trans.) Selected Philosophical Writings (Cambridge: Cambridge University Press), $73-$ 122.

DOSTOEVSKY, F. (1993 [1879]) The Grand Inquisitor, with related chapters from the Brothers Karamazov. Ed. C. Guignon. Trans. C. Garnett (Indianapolis: Hackett).

ELIOT, T. S. (1943) 'Burnt Norton' in Four Quartets (New York: Mariner).

ERIKSON, E. H. (1959) Identity and the Life Cycle (New York: W. W. Norton).

FREUD, A. (1966) The Ego and the Mechanisms of Defense, revised edition (Madison, CT: International Universities Press).

FREUD, S. (1961 [1928]) The Future of an Illusion. Trans. J. Strachey (New York: W. W. Norton).

GARRARD, E. (2002) 'Evil as an Explanatory Concept', The Monist, 85, 320-336

HERMAN, J. L. (1992) Trauma and Recovery: The Aftermath of Violence from Domestic Abuse to Political Terror (New York: Basic).

HOROWITZ, M. J. (1999) Essential Papers on Posttraumatic Stress Disorder (New York: New York University Press).

HUME, D. (2007 [1779]) Dialogues concerning Natural Religion, and Other Writings. Ed. D. Coleman (Cambridge: Cambridge University Press).

JANET, P. (1889) L'Automatisme Psychologique (Paris: Alcan). 
JANOFF-BULMAN, R. (1992) Shattered Assumptions: Towards a New Psychology of Trauma (New York: Free Press).

JONES, K. (1996) 'Trust as an Affective Attitude', Ethics, 107, 4-25.

KEKES, J. (2005) The Roots of Evil (Ithaca, NY: Cornell University Press).

LEAR, J. (1990) Love and Its Place in Nature: A Philosophical Interpretation of Freudian Psychoanalysis (New York: Farrar, Straus, \& Giroux).

LERNER, M. J. (1980) The Belief in a Just World: A Fundamental Delusion (New York: Plenum).

NAGASAWA, Y. (2018) 'The Problem of Evil for Atheists' in N. Trakakis (ed.) The Problem of Evil: Eight Views in Dialogue (Oxford: Oxford University Press), 151-163.

NEIMAN, S. (2002) Evil in Modern Thought: An Alternative History of Philosophy (Princeton: Princeton University Press).

NIETZSCHE, F. (1999 [1872]) The Birth of Tragedy and Other Writings. Eds. R. Geuss \& R. Speirs. Trans. R. Speirs (Cambridge: Cambridge University Press).

NUSSBAUM, M. (1986) The Fragility of Goodness: Luck and Ethics in Greek Tragedy and Philosophy (Cambridge: Cambridge University Press).

PANCHUK, M. (2018) 'The Shattered Spiritual Self: A Philosophical Exploration of Religious Trauma', Res Philosophica, 95, 505-530.

SCHOPENHAUER, A. (2018 [1818]) The World as Will and Representation, Vol 2. Trans and Eds. J. Norman, A. Welchman, \& C. Janaway (Cambridge: Cambridge University Press).

SHAY, J. (1994) Achilles in Vietnam: Combat Trauma and the Undoing of Character (New York: Atheneum).

STOCKER, M. (1983) 'Psychic Feelings: Their Importance and Irreducibility', Australasian Journal of Philosophy, 61, 5-26.

SYMONDS, M. (2010 [1980]) 'The "Second Injury" to Victims of Violent Acts', The American Journal of Psychoanalysis, 70, 34-41.

VAN DER KOLK, B. (2014) The Body Keeps the Score: Mind, Brain, and Body in the Transformation of Trauma (London: Allan Lane).

WINNICOTT, D. W. (1958) Through Paediatrics to Psychoanalysis: Collected Papers (London: Karnac).

${ }^{1}$ There are exceptions to this view. For example, Neiman (2002) has written extensively on the problem of evil from a secular point of view. I consider her work foundational for this paper. Also of note is the work of Kekes (2005) and a recent paper by Nagasawa (2018). Kekes posits a 'secular problem of evil' in which the challenge posed by the existence of evil is one of "explain[ing] how natural conditions could be transformed so as to make evil less widespread' (219). This problem is distinct from the problem I identify here. Nagasawa does not identify the problem he raises under the heading of the 'secular problem of evil.' However, the concerns Nagasawa advances regarding the implications of the existence of evil for atheism bear important similarities to my own.

2 '[P]hilosophy, like the overture to Don Giovanni, begins with a minor chord ... The more precise configuration of the astonishment ... which leads people to philosophize, clearly comes from the sight of the ill and the evil in the world' (Schopenhauer (2018 [1818]), 181). 
${ }^{3}$ Hence, 'two-world' views like those found in literatures influenced by Platonism comprise a single world as understood here.

${ }^{4}$ I am indebted to the psychoanalytic theorist D. W. Winnicott for the notion of a 'good-enough world.' Winnicott is perhaps best known for his concept of the 'good-enough mother.' This notion, however, had its origin in the concept of a good-enough environment, first articulated in his 1949 paper 'Mind and Its Relation to the Psyche-Soma' (reprinted in Winnicott (1958), 243-254).

${ }^{5}$ For the classic treatment of this topic, see Nussbaum (1986).

${ }^{6}$ In speaking of the successful personality, it is not my intention to suggest that every personality ought to be successful. For example, it may be that some personalities are irredeemably destructive and, for that reason, should not succeed.

${ }^{7}$ Here one might note a fourth option: a world which is karmic, yet nonetheless disabling. I suspect that this option entails a contradiction as a karmic world is necessarily enabling in virtue of being karmic. But I leave further consideration to the reader.

8 'Life presents itself as an ongoing deception ... The magic of distance shows us paradises that vanish like optical illusions after we have allowed ourselves to be taken in' (Schopenhauer (2018 [1818]), 588).

${ }^{9}$ For an admirable attempt to secure Kantianism in a nonkarmic world, see Baier (1980). Baier's thesis is that 'the secular equivalent of faith in God ... is faith in the human community and its evolving procedures' (133).

10 'The deity who spoke ... was not Dionysos, nor Apollo, but an altogether newborn daemon called Socrates. This is the new opposition: the Dionysiac versus the Socratic, and the work of art that once was Greek tragedy was destroyed by it' (Nietzsche (1999 [1872]), $60)$.

${ }^{11}$ For foundational work on the mind's defenses, see Freud (1966).

${ }^{12}$ For a philosophical account of trust akin to the one employed in the paper, see Jones (1996).

${ }^{13}$ By this point, one might find oneself entertaining the question of numbers. For example, what if - counterfactually - there was a good-enough environment not merely for some of us, but rather for all of us? Would not such conditions amount to a good-enough actual world? Here, I'm inclined to say that the answer is 'yes.' Many civilizations have aspired to achieve a good-enough environment for all. Should such conditions one day be achieved, that achievement would constitute strong evidence that actual world is enabling, and hence a good-enough world. The problem, of course, is that we are far from knowing whether such conditions are achievable at the present time.

${ }^{14}$ For canonical literature on posttraumatic stress, see Herman (1992), Horowitz (1999), and van der Kolk (2014). For philosophical discussion, see Brison (2002), Panchuk (2018), and Burchard (2019). 
${ }^{15}$ In changing the subject from metaphysics to aesthetics, Camus follows a line of thought laid down by Hegel and Nietzsche. My objections to Camus' views are intended to apply to his predecessors also.

${ }^{16}$ Here, I take Lear to mean 'empirically possible' rather than 'metaphysically possible.'

${ }^{17}$ As with the literature on posttraumatic stress, I intend my views to be broadly compatible with the literature on psychoanalytic theory. Where Lear speaks of a 'lovable world', I speak of a 'good-enough world'; where Lear speaks of 'the ego', I speak of 'the personality'. I have reconstructed Lear's arguments accordingly.

${ }^{18}$ Here one might wonder why Lear holds that 'a world that is not loveable (by beings like us) is not a possible world'. I regret that despite my best efforts, Lear's reasons for asserting this claim remain unclear to me.

${ }^{19}$ The 'second injury' is a 'lack of expected support from the community, agencies, treating personnel, society in general, as well as family or friends to an individual who has been injured or victimized' ((2010 [1980]) 37).

${ }^{20}$ For insightful analysis and discussion, see Adams (1989).

21 '[The tears of the children who have been tortured] must be atoned for, or there can be no harmony. But how? How are you going to atone for them? Is it possible? By their being avenged? What do I care for a hell for oppressors? What good can hell do, since those children have already been tortured?' (Dostoevsky (1993 [1879]), 15-16).

${ }^{22} \mathrm{Here}$, I assume that atheists endorse the argument from evil as a powerful argument in favor of atheism. Of course, this assumption need not be true of any particular atheist. One can be an atheist without it.

23 'Some years ago I was struck by the large number of falsehoods that I had accepted as true in my childhood, and by the highly doubtful nature of the whole edifice I had subsequently based on them' (Descartes (1988 [1641]), 76).

24 'The possibility of radical evil both destroys and institutes the religious' (Derrida (1996), 100).

${ }^{25}$ Acknowledgments to Fred Beiser, John Bishop, Ben Bradley, Robert W. Daly, Elizabeth Hegeman, Carrie Jenkins, Cathy Mason, Kris McDaniel, Adam Morton, Michael Stocker, Leigh C. Vicens, Margaret Urban Walker, and multiple anonymous referees for helpful comments on previous drafts of this paper. Additional acknowledgements to audiences at the 2015 conference on analytic existentialism at Boğaziçi University and the 2018 Vancouver Summer Philosophy Conference at the University of British Columbia, with special thanks to Jonathan Ichikawa, Irem Kurtsal, Laurie Paul, and Eric Schliesser. 